\section{Isolation and Characterization of 17 Polymorphic Microsatellite Loci for Musella lasiocarpa (Musaceae)}

\author{
Chun-yan Yang
}

Key Laboratory of Biodiversity and Biogeography, Kunming Institute of Botany, Chinese Academy of Sciences, Kunming 650204, Yunnan, China; and Graduate School, Chinese Academy of Sciences, Beijing 100039, China

\section{Yuan Huang}

Key Laboratory of Biodiversity and Biogeography, Kunming Institute of Botany, Chinese Academy of Sciences, Kunming 650204, Yunnan, China

\section{Chunlin Long ${ }^{1}$}

Key Laboratory of Biodiversity and Biogeography, Kunming Institute of Botany, Chinese Academy of Sciences, Lanhei Road 134, Heilongtan, Kunming 650204, Yunnan, China; and College of Life and Environmental Sciences, Minzu University of China, Beijing 100081, China

Additional index words. Chinese dwarf banana, golden lotus banana, molecular makers, population genetics

Abstract. Seventeen microsatellite markers were isolated from 24 wild individuals collected from three populations of Musella lasiocarpa (Franch.) C. Y. Wu ex H. W. $\mathrm{Li}$, a plant endemic to southwest China. The average allele number of these markers was 3.6 per locus, ranging from two to seven. The expected $(\mathrm{He})$ and observed $(\mathrm{Ho})$ heterozygosities varied from 0.4672 to 0.8183 and from 0.0417 to 1 , respectively. Eleven loci were significantly deviated from Hardy-Weinberg equilibrium as a result of the heterozygote deficiency. These microsatellite primers will be used for studying genetic population structure and genetic diversity of M. lasiocarpa.

Musella lasiocarpa, commonly referred to as Chinese dwarf banana or golden lotus banana, is native to the watersheds of the Upper Yangtze River of Yunnan and Sichuan provinces in southwest China (Wu and Kress, 2000). It is a synonym of Musa lasiocarpa Franch. (Cheesman, 1947) and Ensete lasiocapum (Franch.) E. E. Cheesman (Simmonds, 1960). Different from the triploids with various combinations of $\mathrm{A}$ and $\mathrm{B}$ genomes of Musa, Musella lasiocarpa is diploid with a chromosome number $2 \mathrm{n}=18$ (Isobe and Hashimoto, 1994). With its showy golden yellow flowers, which can last up to 7 months (Liu et al., 2003), and abroad ecological environment adaptability, this species has attracted some horticulturists from the United States, the United Kingdom, European Union, and Japan, who have taken an interest in the commercial development of this resource as

\footnotetext{
Received for publication 25 June 2009. Accepted for publication 10 Sept. 2009.

This work was supported by the Ministry of Science and Technology of China (2008FY110400-2-2 and 2005DK21006), the Ministry of Education of China (B08044 and CUN-985-3-3), and the Japan Society for the Promotion of Science (JSPS/AP/109080).

Dr. Anjun Tang and Yitao Liu made contributions in collecting samples from the fields.

C.-y. Yang and Y. Hang contributed equally.

${ }^{1}$ To whom reprint requests should be addressed; e-mail long@mail.kib.ac.cn.
}

an ornamental (Long et al., 2008). Aside from the decorative value, the use of $M$. lasiocarpa has also been reported as medicine, winebrewing, weaving material, source plant for honey, pig fodder, and as valuable for soil and water erosion control (Liu et al., 2003; Long, 1997; Long et al., 2008). Although this plant has been introduced to various regions and botanical gardens and has been cultivated widespreadly in Yunnan, the wild populations of $M$. lasiocarpa are rare as a result of highly fragmented habitats (Liu et al., 2002). To provide effective conservation and management, better understanding of the wild population genetic structure of this species is important. In this study, we reported the characterization of 17 polymorphic microsatellite loci to investigate genetic structure among populations of $M$. lasiocarpa for further conservation genetic studies.

\section{Materials and Methods}

Twenty-four Musella lasiocarpa individuals from three populations were used in our study (Table 1). Genomic DNA samples were extracted using the cetyltrimethylammonium bromide extraction method (Milligan, 1992). The isolation method of loci was performed according to the fast isolation by amplified fragment length polymorphism of sequences containing repeats (Zane et al., 2002). Briefly, $\approx 300$ ng genomic DNA was digested with a restriction enzyme-MseI (Fermantas) and ligated to an MseI adaptor pair (Vos et al., 1995); then $5 \mu \mathrm{L}$ of ligation products acted as templates to perform polymerase chain reaction (PCR) in a volume of $20 \mu \mathrm{L}$ using MseI-N primers (5'-GAT GAG TCC TGA GTA AN-3') and following the program: $95^{\circ} \mathrm{C}$ for $3 \mathrm{~min}, 30$ cycles of $94^{\circ} \mathrm{C}$ for $30 \mathrm{~s}, 53{ }^{\circ} \mathrm{C}$ for $60 \mathrm{~s}, 72^{\circ} \mathrm{C}$ for $60 \mathrm{~s}$, followed by $72{ }^{\circ} \mathrm{C}$ for $5 \mathrm{~min}$.

For enrichment, the PCR products were denatured at $95{ }^{\circ} \mathrm{C}$ for $5 \mathrm{~min}$ and then were hybridized with $5^{\prime}$-biotinylated probe $(\mathrm{AG})_{15}$ in a $250 \mu \mathrm{L}$ solution $(20 \times \mathrm{SSC}, 10 \%$ SDS, $100 \mathrm{pmol} / \mu \mathrm{L})$ at $48{ }^{\circ} \mathrm{C}$ for $2 \mathrm{~h}$. The DNA hybridized to the probe was separated and captured by streptavidin-coated magnetic beads at room temperature for $20 \mathrm{~min}$ followed by two washing steps, including three times in $\mathrm{TEN}_{100}$ for $15 \mathrm{~min}$ and three times in $\mathrm{TEN}_{1000}$ for $24 \mathrm{~min}$. The separated singlestranded DNA was subjected to a second round of PCR according to the same procedure as the first round of PCR. The PCR products, purified with the E.Z.N.A Gel Extraction Kit (Omega Bio-Tek, USA), were ligated into PMD18-T vector (Takara, Japan) according to the manufacturer's instructions and then transformed into Escherichia coli strain JM109 (Sangon, China). The positive clone was picked out by blue-white screening and tested by PCR using (AG) 10 and

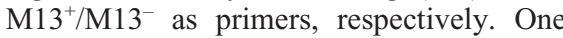
hundred fifty-five of 277 screened clones contained potential microsatellite motifs.

A total of 100 clones $(67 \%)$ were found to contain simple sequence repeat and then subjected to primer designing using the Primer 5.0 (Clarke and Gorley, 2001). Twenty-four $M$. lasiocarpa individuals from three wild populations were used to screen polymorphism. PCR reaction was done in $20 \mu \mathrm{L}$ volume using PTC200 thermal cycler (MJ Research, USA). Each reaction was performed using $20 \mathrm{ng}$ of genomic DNA, $0.1 \mathrm{~mm}$ of each dNTP, $1 \mu \mathrm{M}$ each primer, $1 \times$ Taq buffer $[100$ mм Tris- $\mathrm{HCl}, \mathrm{pH} 8.0,2.0 \mathrm{~mm} \mathrm{MgCl}_{2}, 200$ $\mathrm{mm}(\mathrm{NH} 4)_{2} \mathrm{SO}_{4}, 0.1 \%$ Tween 20$]$ and $1 \mathrm{U}$ of Taq polymerase (Takara). The PCR programs took place as follows: initial denaturing step at $95^{\circ} \mathrm{C}$ for $5 \mathrm{~min}, 30$ cycles of $94^{\circ} \mathrm{C}$ for $30 \mathrm{~s}$, primer-specific annealing temperature 55 to $62{ }^{\circ} \mathrm{C}$ for $30 \mathrm{~s}, 72{ }^{\circ} \mathrm{C}$ for $30 \mathrm{~s}$, and a final extension step at $72{ }^{\circ} \mathrm{C}$ for $8 \mathrm{~min}$. The PCR products were electrophoresized in denaturing $6 \%$ polyacrylamide gels using a 25 -bp DNA ladder molecular size standard (Fermantas) to estimate allele sizes by silver staining.

\section{Results and Discussion}

Of these 42 new primers designed for M. lasiocarpa, 28 successfully amplified the target regions and 17 of them displayed polymorphism. Results of the allele number, expected $\left(H_{e}\right)$ and observed $\left(H_{o}\right)$ heterozygosities and Hardy-Weinberg equilibrium $(P)$ were calculated by GENEPOP version 3.4 (http://genepop.curtin.edu.au/) (Raymond and Rousset, 1995). The number of alleles per locus ranged from two to seven (Table 2). The 
Table 1. Sample information of Musella lasiocarpa.

\begin{tabular}{|c|c|c|c|c|c|}
\hline Species & Distribution & Habitat & Altitude (m) & Position & Sample size \\
\hline $\begin{array}{l}\text { Musella } \\
\quad \text { lasiocarpa }\end{array}$ & $\begin{array}{l}\text { Bingju, Dali, Yunnan } \\
\text { Province }\end{array}$ & Limestone mountain & 1795 & $\begin{array}{l}\text { Lat. E } 100^{\circ} 30^{\prime} 59.7^{\prime \prime} \\
\quad \text { long. N } 25^{\circ} 40^{\prime} 38.1^{\prime \prime}\end{array}$ & 8 \\
\hline $\begin{array}{l}\text { Musella } \\
\quad \text { lasiocarpa }\end{array}$ & $\begin{array}{l}\text { Jingjiang, Lijiang, Yunnan } \\
\text { Province }\end{array}$ & $\begin{array}{l}\text { Steep mountain beside } \\
\text { Jingsha River xerothermic valley }\end{array}$ & 1870 & $\begin{array}{l}\text { Lat. E } 100^{\circ} 25^{\prime} 57.0^{\prime \prime}, \\
\quad \text { long. N } 26^{\circ} 58^{\prime} 58.0^{\prime \prime}\end{array}$ & 8 \\
\hline $\begin{array}{l}\text { Musella } \\
\quad \text { lasiocarpa }\end{array}$ & $\begin{array}{l}\text { Qinhe, Yanyuan, Sichuan } \\
\text { Province }\end{array}$ & $\begin{array}{l}\text { Steep mountain beside Jingsha River } \\
\text { xerothermic valley }\end{array}$ & 1400 & $\begin{array}{l}\text { Lat. E } 101^{\circ} 24^{\prime} 07.2^{\prime \prime}, \\
\quad \text { long. N } 27^{\circ} 04^{\prime} 39.5^{\prime \prime}\end{array}$ & 8 \\
\hline
\end{tabular}

Table 2. Primer sequences, repeat motif, size range, annealing temperature $(T a)$, number of alleles $(A)$, expected $(H e)$ and observed $\left(H_{o}\right)$ heterozygosities, and significance of deviation from Hardy-Weinberg equilibrium $(P<0.01)$ for 17 microsatellite primers from Musella lasiocarpa.

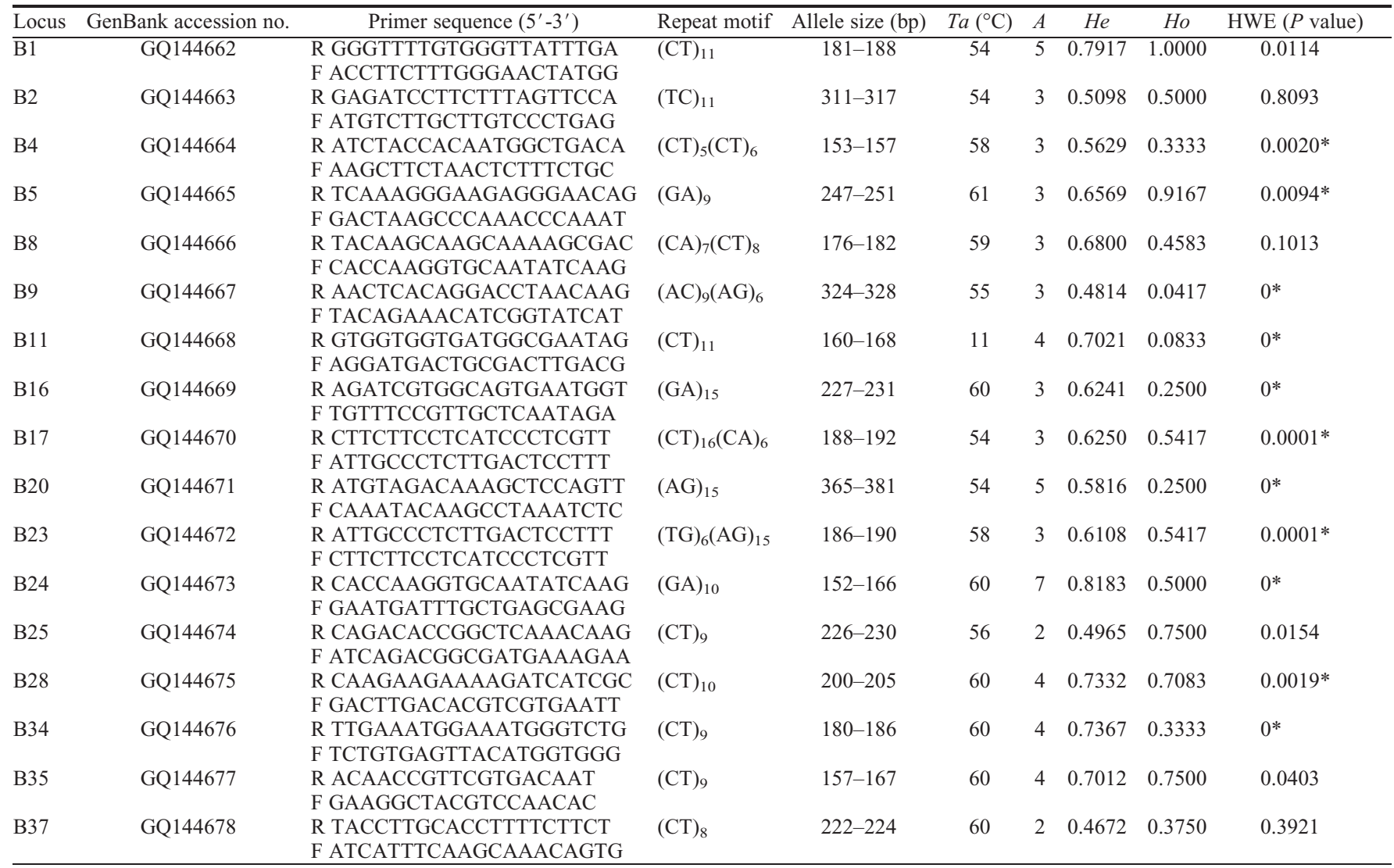

*Significant deviation from Hardy-Weinberg equilibrium (HWE) $(P<0.01)$.

expected $\left(H_{e}\right)$ and observed $\left(H_{o}\right)$ heterozygosities ranged from 0.4672 to 0.8183 and 0.0417 to 1 , respectively. Among 17 microsatellite markers, 11 loci showed significant deviation from Hardy-Weinberg equilibrium $(P<0.01)$, probably due to deficiency of heterozygote or the limitation of sample size. Tests for linkage disequilibrium were run in FSTAT Version 2.9.3.2 (Goudet, 1995). Significance levels were adjusted using sequential Bonferroni corrections (Rice, 1989). No loci showed significant linkage disequilibrium after Bonferroni correction.

The polymorphic microsatellite loci presented here would be useful for studying the population genetic structure and genetic diversity of $M$. lasiocarpa, which would help us to better understand the wild Musella population and then to provide effective conservation and management.

\section{Literature Cited}

Cheesman, E.E. 1947. The classification of the bananas. Kew Bull. 2:97-117.
Clarke, K.R. and R.N. Gorley. 2001. PRIMER v5: User manual/tutorial. PRIMER-E Ltd., Plymouth, UK.

Goudet, J. 1995. FSTAT (Version 1.2): A computer program to calculate F-statistics. J. Hered. 86:485-486

Isobe, M. and K. Hashimoto. 1994. The chromosome count of nine taxa in Musa and its allied genus Musella. Bull. Hiroshima Bot. Gard. 15:7-11.

Liu, A.Z., W.J. Kress, and C.L. Long. 2003. Customary use and conservational attention to Musella lasiocarpa (Musaceae): A monotypic genus endemic to China. Econ. Bot. 57:279-281.

Liu, A.Z., W.J. Kress, H. Wang, and D.Z. Li. 2002. Insect pollination of Musella lasiocarpa (Musaceae), a monotypic genus endemic to Yunnan, China. Plant Syst. Evol. 235:135-146.

Long, C.L. 1997. The development potential of Musella lasiocarpa, p. 168-176. In: Yunnan Association of Science and Technology, Proc. of Workshop on Enterprises and Marketing of Special Animals and Plants in Yunnan. Kunming, China.

Long, C.L., A. Selena, X.R. Wang, Y.T. Liu, B. Long, C.Y. Yang, Y.N. Shi, X.Y. Li, and R Guo. 2008. Why Musella lasiocarpa (Musa- ceae) is used in southwest China to feed pigs. Econ. Bot. 62:182-186

Milligan, B. 1992. Plant DNA isolation, p. 58-88. In: Hoelzel, A.R. (ed.). Molecular genetic analysis of populations: A practical approach. IRL Press, Oxford, UK.

Raymond, M. and F. Rousset. 1995. GENEPOP (version 1.2): Population genetics software for exact tests and ecumenicism. J. Hered. 86:248249.

Rice, W.R. 1989. Analyzing tables of statistical tests. Evolution 43:223-225.

Simmonds, N.W. 1960. Notes on banana taxonomy. Kew Bull. 14:198-212.

Vos, P., R. Hogers, M. Bleeker, M. Reijans, T. van de Lee, M. Hornes, A. Frijters, J. Pot, J. Peleman, and M. Kuiper. 1995. AFLP: A new technique for DNA fingerprinting. Nucleic Acids Res. 23:4407-4414.

Wu, D.L. and W.J. Kress. 2000. Musaceae, p. 314 318. In: Wu, C.Y. and P.H. Raven (eds.). Flora of China. Vol. 24 (Flagellariaceae through Marantaceae). Science Press, Beijing, China, and Missouri Botanical Garden Press, St. Louis, MO.

Zane, L., L. Bargelloni, and T. Patarnello. 2002. Strategies for microsatellite isolation: A review. Mol. Ecol. 11:1-16. 